\title{
L-Glutamine Supplementation Associated With Moderate Aerobic Training Improves Biometric, Glycemic Profile and the Antioxidant Defense
}

\author{
Analú Bender dos Santos, ${ }^{1}$ Lílian Corrêa Costa-Beber, ${ }^{2}$ \\ Eloisa Gabriela de Pelegrin Basso, ${ }^{3}$ Pauline Brendler Goettems Fiorin, ${ }^{3}$ \\ Renan Daniel Bueno Basso, ${ }^{1}$ Maicon Machado Sulzbacher, ${ }^{1}$ \\ Mirna Stela Ludwig, ${ }^{1}$ Thiago Gomes Heck ${ }^{1}$
}

\begin{abstract}
Introduction: L-glutamine is a non-essential amino acid, whose pool appears to be depleted during catabolic conditions, such as intense or high duration exercise, and to avoid the exercise- related benefits. Therefore, its supplementation could provide an additional source of L-glutamine and prevent these effects. However, the oral intake of its free form has been discouraged, despites of some evidences reporting positive effects. Objective: to verify whether the L-glutamine supplementation (in its free form) could provide an additional improvement in biometric, glycemic and redox parameters, in animals undergoing moderate aerobic training (MAT). Methods: 28 Swiss male mice were divided into four groups: Cont ( $n=7)$, Ex $(n=7)$, Glut $(n=8)$, and $E x+G l u t(n=6)$. Glut and Ex+Glut received gastric gavage of L-glutamine $(1 \mathrm{~g} / \mathrm{kg})$, while Cont and Ex groups received $100 \mu \mathrm{L}$ of PBS one hour before exercising, five days/week, six weeks. Ex and Ex+Glut underwent moderate swimming, while Cont and Glut remained sedentary, for the same period. Mice started swimming with $2 \%$ of body weight attached to the tail during $20 \mathrm{~min}$, and ended the experiment with $4 \%$ during $60 \mathrm{~min}$. Results: L-glutamine supplementation increased the gastrocnemius mass and improved the glucose tolerance in animals submitted to MAT. It improved the antioxidant status in gastrocnemius, liver and pancreas, and declined it in adipose tissue in animals undergoing MAT. The drop of adipose antioxidant defense was associated with adiposity, while pancreas antioxidant activity was inversely associated with the glucose intolerance. Conclusion: L-glutamine (free form) improves biometric and glucose parameters, and enhances antioxidant activities.
\end{abstract}

Keywords: Glucose intolerance. Oxidative stress. HSP70. Skeletal muscle. Adiposity

SUPLEMENTAÇÃO DE L-GLUTAMINA ASSOCIADA AO TREINAMENTO AERÓBICO MODERADO MELHORA PERFIL BIOMÉTRICO E GLICÊMICO E A DEFESA ANTIOXIDANTE

RESUMO

Introdução: L-glutamina é um aminoácido não essencial, cujo 'pool' intracelular parece ser depletado durante condições catabólicas, como exercício intenso ou de longa duração, e assim inibir os benefícios relacionados ao exercício. Portanto, a sua suplementação pode fornecer uma fonte adicional de L-glutamina e prevenir esses efeitos. No entanto, a ingestão oral da sua forma livre tem sido desencorajada, apesar de algumas evidências reportando efeitos positivos. Objetivo: verificar se a suplementação de L-glutamina (na sua forma livre) pode proporcionar uma melhora adicional em parâmetros biométricos, glicêmicos e redox, em animais submetidos ao treinamento aeróbico moderado (MAT). Métodos: 28 camundongos Swiss machos foram divididos em quatro grupos: Cont $(n=7)$, $E x(n=7)$, Glut $(n=8)$, e Ex+Glut ( $n=6)$. Glut e Ex+Glut receberam gavagem gástrica de L-glutamina $(1 \mathrm{~g} / \mathrm{kg}$ ), enquanto os grupos Cont e Ex receberam $100 \mathrm{uL}$ de PBS uma hora antes do exercício, cinco dias/semana, seis semanas. Ex e Ex+Glut foram submetidos a natação moderada, enquanto Cont e Glut permaneceram sedentários, durante o mesmo período. Os camundongos iniciaram a natação com $2 \%$ do peso corporal acoplado a cauda durante 20 min, e terminaram o experimento com 4\% durante 60 min. Resultados: A suplementação de L-glutamina aumentou a massa do gastrocnêmio e melhorou a tolerância a glicose nos animais submetidos ao MAT. Ela melhorou o estado antioxidante no gastrocnêmio, fígado e pâncreas, e reduziu no tecido adiposo branco em animais passando por MAT. A redução da defesa antioxidante do tecido adiposo esteve associada a adiposidade, enquanto a atividade antioxidante pancreática foi inversamente associada a intolerância a glicose. Conclusão: L-glutamina (forma livre) melhora parâmetros biométricos e glicêmicos, e aumenta as atividades antioxidantes.

Palavras-chave: Intolerância a glicose. Estresse oxidativo. HSP70. Músculo esquelético. Adiposidade.

RECEBIDO EM: 25/8/2020

MODIFICAÇÕES SOLICITADAS EM: 9/9/2020

ACEITO EM: 20/9/2020

\footnotetext{
Regional University of Northwestern Rio Grande do Sul State (Unijuí). Rua do Comércio, 3000 - Bairro Universitário. Ijuí/RS, Brazil. CEP $98700-000$.

${ }_{2}^{2}$ Autora correspondente. Regional University of Northwestern Rio Grande do Sul State (Unijuí). Rua do Comércio, 3000 - Bairro Universitário. Ijuí/RS, Brazil. CEP 98700-000. http://lattes.cnpq.br/2752820101075796. https://orcid.org/0000-0001-7796-1641. liliantutty@hotmail.com

${ }^{3}$ Regional University of Northwestern Rio Grande do Sul State (Unijuí). Rua do Comércio, 3000 - Bairro Universitário. Ijuí/RS, Brazil. CEP 98700-000; Atmospheric Pollution Laboratory, Postgraduate Program in Health Sciences, Federal University of Health Sciences of Porto Alegre (UFCSPA). Rua Sarmento Leite, 245. Porto Alegre/RS, Brazil.
} 


\section{INTRODUCTION}

The dietary supplementation L-glutamine has been discussed worldwide regardless its efficacy in preventing muscle fatigue (COQUEIRO; ROGERO; TIRAPEGUI, 2019), in catabolic conditions such as hind limb immobilization (PETRY et al., 2019), sepsis (SULZBACHER et al., 2018) and aerobic physical training (PETRY et al., 2014). L-glutamine is one of the most abundant amino acids in the circulation, and can act in the glycemic control by increasing the insulin production and secretion (CARLESSI et al., 2019; COQUEIRO; ROGERO; TIRAPEGUI, 2019). Besides, the most important role of glutamine is the indirect antioxidant activity through enhancing glutathione availability and the $70 \mathrm{kDa}$-heat shock protein (HSP70) expression (PETRY et al., 2019). The HSP70 is a high evolutionarily conserved chaperone, expressed under stressful conditions, with a fundamental antioxidant, anti-inflammatory role (MIRAGEM; HOMEM DE BITTENCOURT, 2017), and sensible to exercise (HECK et al., 2017), diabetes (BITTENCOURT et al., 2020) and glutamine levels (PETRY et al., 2014, 2015, 2019).

The main endogenous source of L-glutamine is the skeletal muscle under activity, besides also being produced by adipose tissue and liver (COQUEIRO; ROGERO; TIRAPEGUI, 2019). By challenging our body through an increase of oxidative metabolism and the production of reactive oxygen species (ROS), the exercise can deplete the L-glutamine pool (CRUZAT et al., 2018) and overload the antioxidant defense depending on its intensity and duration. This depletion is followed by an increased release of oxidative stress biomarkers, which can affect other metabolic tissues, and compromise the exercise-related benefits. Moderate physical aerobic training is a non-pharmacological strategy to treat or prevent metabolic conditions, which can, at long-term lead to type II diabetes mellitus (DM2) (PEDERSEN, 2017; WEDELL-NEERGAARD et al., 2018a).

The moderate training-related benefits are related to the amelioration of body composition, with a significant reduction of the adiposity and a stabilization or increase of lean mass, both related to the improvement of glycemic homeostasis (WEDELL-NEERGAARD et al., 2018a). By enhancing the muscle content, exercise helps in contra balancing the inflammatory and oxidative phenotype displayed by adipocytes, in a 'yin-yang' relationship (PEDERSEN, 2013, 2017). Therefore, and can be considered a "real poIy-pill" (FIUZA-LUCES et al., 2013), since also enhances the antioxidant defense, which depends on the L-glutamine availability.
L-glutamine deprivation induces metabolic adaptations, such as reduction of glucose uptake, insulin production and release, as well as a drop in the mitochondrial respiration, both associated with a $\beta$-cells dysfunction (CARLESSI et al., 2019). Therefore, the L-glutamine supplementation could provide an exogenous source of this amino acid, and improve the glycemic, glutathione and inflammatory profile. However, although some studies report benefits (MEDRAS et al., 2018; ABBOUD et al., 2019; ALMEIDA et al., 2020), recently the oral intake of L-glutamine in its free form has been discouraged, due to its utilization for the enterocytes supply (CRUZAT et al., 2018). Nevertheless, if it works in stimulating other antioxidant enzymes than the glutamine-glutathione-HSP70 axis (PETRY et al., 2014, 2015, 2019), and if it has a synergistic effect with moderate aerobic training these parameters remains unclear.

Here, we propose to associate the L-glutamine supplementation in the moderate aerobic training, to verify if the supplementation could provide an additional improvement in biometric, glycemic parameters, by protecting metabolic tissues from oxidative damage and enhancing the muscle HSP70 expression in animals undergoing moderate aerobic training.

\section{MATERIAL AND METHODS}

\section{Animals}

We utilized 28 Swiss male mice, with 90 days old ( $35 \pm 3$ grams), obtained from the Animal Facility of the Regional University of Northwestern of Rio Grande do Sul State (Unijuí). During the experimental period, the animals were maintained in semi-metabolic boxes (5-6 animals/box), with controlled ambient temperature $\left(22 \pm 2^{\circ} \mathrm{C}\right)$ and a light-dark cycle of 12 hours. All animals received water and standard diet (Nuvilab CR-1) ad libitum.

This study followed all ethical rules established by Arouca's Act (Federal Law 11794/2008) and the Guide for Care and Use of Experimental Animals, published by the National Institutes of Health (NIH publication no. 85-23, revised in 1996) and was approved by the Animal Ethics Committee of Unijuí (Ceua-Unijuí, protocol no 017/2013).

\section{Experimental design}

Animals were divided into four experimental groups: Control group (Cont, $n=7$ ), Exercise $(E x, n=$ 7), Glutamine (Glut, $n=8$ ), and Exercise + Glutamine $(E x+$ Glut, $n=6)$. Glut and $E x+$ Glut received gas- 
tric gavage of L-glutamine $(1 \mathrm{~g} / \mathrm{kg})$, while Cont and Ex groups received the same volume of PBS, adjusted by the body weight, one hour before exercising. Ex and Ex + Glut were submitted to moderate swimming, while Cont and Glut remained physical inactive (sedentary), in the shallow water, five days/week, for six weeks (Figure 1A).

\section{Swimming protocol}

Prior to experiment, all animals were allowed to accustom to the water environment to avoid any stress response related to the new situation and environment. Thus, for three consecutive days, all animals received gastric gavage of $100 \mu \mathrm{L}$ PBS pH 7.4 one hour before were submitted to the water environment. The animals were kept for $10 \mathrm{~min}$ in individual swimming pool chambers $(10 \mathrm{~cm} \times 10 \mathrm{~cm} \times 30 \mathrm{~cm})$ filled with water at $31 \pm 1^{\circ} \mathrm{C}(20 \mathrm{~cm}$ depth), for three consecutive days, without any overload, to avoid stress behavior during exercise training sessions. Afterwards, animals remained three days without manipulation and were further assigned into each experimental groups (Sedentary: Cont and Glut or Trained: Ex and Ex+Glut i.g.).

During the swimming protocol, as in the acclimatization, all animals were maintained in individual swimming pool chambers $(10 \mathrm{~cm} \times 10 \mathrm{~cm} \times 30 \mathrm{~cm})$ filled with water at $31 \pm 1^{\circ} \mathrm{C}$. The sedentary (Cont and Glut) groups remained at rest in shallow water $(2 \mathrm{~cm}$ depth), while the trained (Ex and Ex+Glut) groups swam in $20 \mathrm{~cm}$ depth, as previously described (MAI et al., 2017; KOSTRYCKI et al., 2019) (Figure 1B). The individual pool chambers with $20 \mathrm{~cm}$ of water prevents jumping and diving behavior and allows energy expenditure higher than three metabolic equivalents (METs) (KREGEL et al., 2006; KOSTRYCKI et al., 2019).

In the first week, Ex and Ex + Glut swan with $2 \%$ of body weight (b. w.) of workload attached to the tail during $20 \mathrm{~min}$. In the second week, the workload increased to $4 \%$ b. w., but the duration remained unchanged. From the third to the sixth week, the animals continued swimming with $4 \%$ b. w. workload, but the time increased 10 min per week, ending the experiment with 60 min of swimming with $4 \%$ b. w. workload (Figure 1C). Mice were weekly weighted and the workload adjusted according to it, respecting the training protocol.

All experiments were carried out between 7:00 and midday, and the room temperature was kept at $24^{\circ} \mathrm{C}$. They were monitored by an experienced researcher to prevent drowning, in agreement with The American Physiological Society's Resource Book for the Design of Animal Exercise Protocols (KREGEL et al., 2006). Fatigue was considered when animal stayed eight seconds with the snout underwater, as previously described (MAl et al., 2017; KOSTRYCKI et al., 2019). A previous study of our lab already demonstrated that mice trained with $4 \%$ of workload reached a lactate concentration of $4.54 \pm 0.21 \mathrm{mmol} / \mathrm{L}$ in the $5^{\text {th }}$ week (SCHOLER et al., 2016; MAl et al., 2017). It is hypothesized that $4.0-4.6 \%$ workloads in swimming would reach a moderate intensity range of $60-75 \%$ of $\mathrm{VO}_{2}$ max (KREGEL et al., 2006; MAl et al., 2017).

\section{Diet and L-Glutamine supplementation}

All experimental animals received a standard diet (Nuvilab CR-1, commercially obtained from $\mathrm{Nu}$ vital Nutrientes $S A$ ), which contains crude protein, mineral material, fibrous matter and minerals. The standard diet presents a total metabolizable energy of $16.6 \mathrm{MJ} / \mathrm{kg}$, being $11.4 \%$ as fats, $62.8 \%$ as carbohydrates, and $25.8 \%$ as proteins (GOETTEMS-FIORIN et al., 2016). A more detailed description of the diet is present in the Supplementary Table S1.

L-Glutamine (m. w. $146 \mathrm{~g} / \mathrm{mol}$, Ajinomoto, Brazil) was administered in the dose of $1 \mathrm{~g} / \mathrm{kg} \mathrm{b}$. w. For this, we prepared a solution in the concentration of $1 \mathrm{~g} / 10 \mathrm{~mL}$ in phosphate-buffered saline (PBS) $\mathrm{pH}$ 7.4. Each animal received the volume corresponding to its body weight, by gastric gavage administration, one hour before exercising. We weekly monitored the animal's body weight and adjusted the L-glutamine volume. Therefore, every week, animals received a different volume of the L-glutamine solution, respecting the original dose.

The time of one hour before exercising was considered due to the fact that approximately 30 minutes are required until the increase of glutamine blood concentration after oral intake, which returns to baseline about two hours later (CASTELL; POORTMANS; NEWSHOLME, 1996). Besides, the dose of $1 \mathrm{~g} / \mathrm{kg} \mathrm{b} . \mathrm{w}$ combined to L-alanine in its free form or in the dipeptide form (L-alanyl-L-glutamine) was recently reported to prevent oxidative damage and muscle loss in models of hindlimb immobilization-induced disuse muscle atrophy (PETRY et al., 2019) and in aerobic exercise (PETRY et al., 2014), and the immune dysfunction in sepsis in its free and isolated form (SULZBACHER et al., 2018).

\section{Biometric Profile}

Body weight was monitored weekly with a semi-analytical scale. We also verified the naso-anal length $(\mathrm{cm})$ to perform Lee Index at the $3^{\text {rd }}$ and $6^{\text {th }}$ weeks. 
Figure 1 - Experimental design

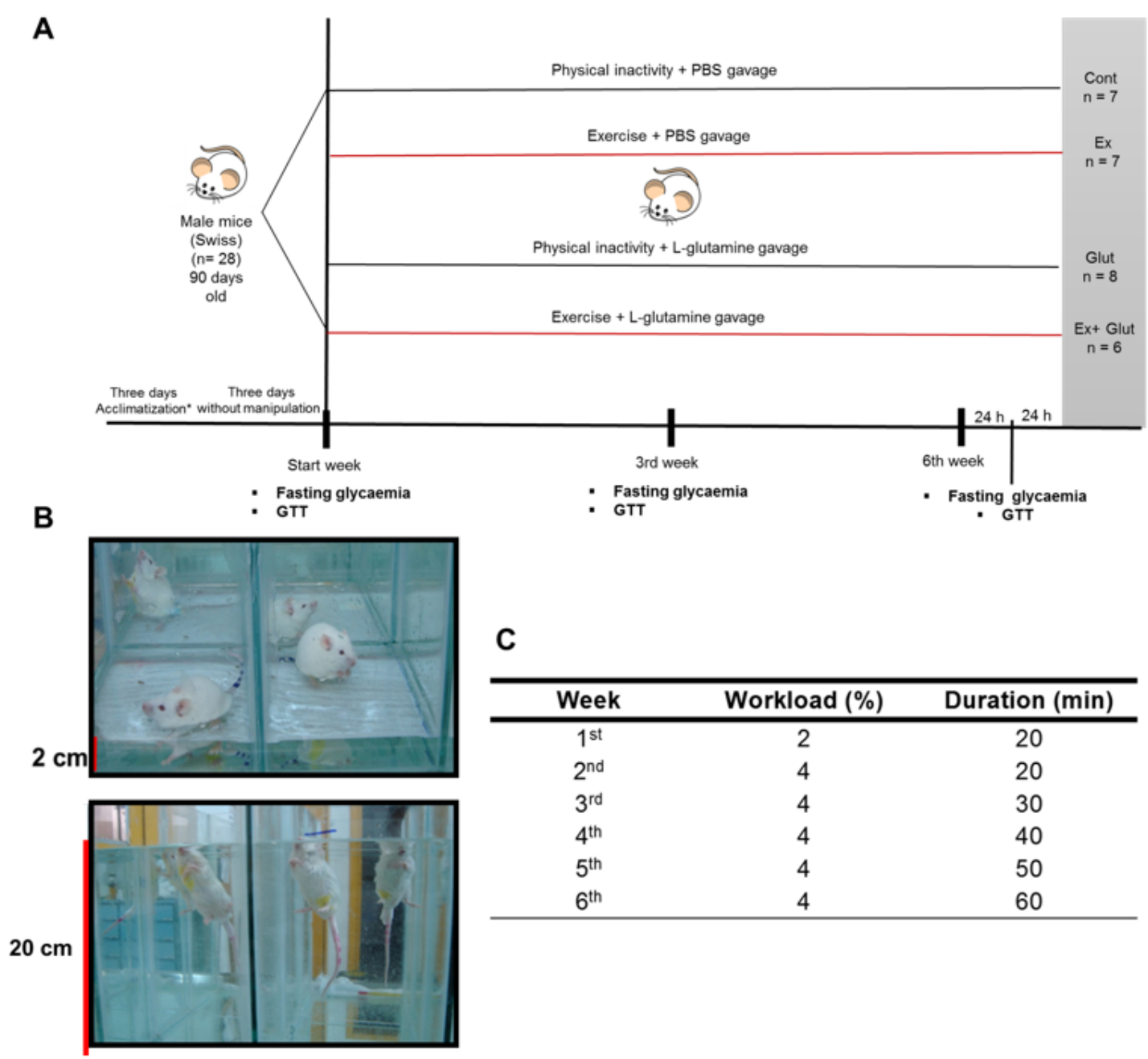

A) Animals underwent three days of acclimatization to the water environment. They received $100 \mu \mathrm{L}$ of PBS by gastric gavage and one hour later were kept for $10 \mathrm{~min}$ in individual swimming pool chambers filled with water, for three consecutive days, without any overload, to avoid stress behavior during exercise training sessions. Animals remained three days without any manipulation and were further assigned into four experimental groups: Glut and Ex + Glut received glutamine $(1 \mathrm{~g} / \mathrm{kg})$, diluted in PBS pH 7.4 by gastric gavage, while Cont and Ex groups received $100 \mu \mathrm{L}$ of PBS one hour before exercising. Ex and Ex + Glut were submitted to moderate swimming, while Cont and Glut remained physical inactive (sedentary), in the shallow water, five days/week, for six weeks. Body weight was verified weekly, fasting glycaemia and glucose tolerance at the baseline, third and sixth weeks. At the end of the sixth week, after the last glucose tolerance test (GTT) and 48 hours without intervention, animals were euthanized with guillotine. B) During experimental design, the sedentary animals (Cont and Glut groups) were kept in shallow water $\left(2 \mathrm{~cm}\right.$ depth; $\left.31 \pm 1^{\circ} \mathrm{C}\right)$ during each training session, while the active animals (Ex and Ex $\left.+\mathrm{Glut}\right)$ were kept in a water ( $20 \mathrm{~cm}$ depth; $\left.31 \pm 1^{\circ} \mathrm{C}, 20 \mathrm{~min}\right)$. C) Schematic protocol of moderate swimming. The animals started the protocol with $2 \%$ b. w. workload attached to the tail during $20 \mathrm{~min}$. In the second week, the workload increased for $4 \% \mathrm{~b}$. w., but the duration remained stable. From the third to the sixth weeks, the time enhanced 10 min per week with the $4 \%$ b. w. workload, ending the experiment swimming with $4 \%$ b.w. attached to the tail during 60 min.

Font: The authors.

Lee Index was calculated by dividing the cube root of the animal's body weight ( $\mathrm{g}$ ) by naso-anal distance (cm) (LEE, 1929). At the end of the experiment, we evaluated adiposity [\% of epididymal white adipose tissue (Ewat)/body weight] and \% of liver, pancreas, gastrocnemius and soleus muscle relative to body weight.

\section{Glycaemia and Glucose Tolerance Test (GTT)}

Blood glucose levels were monitored at the baseline, at $3^{\text {rd }}$ and $6^{\text {th }}$ weeks, in the morning after the last exercise session. Blood glucose was measured by
Glucometer Optium Xceed (Abbott Diabetes Care, Alameda, USA) ( $5 \mu \mathrm{L}$ of blood) after 12 hours of fasting. The glycaemia results were expressed in $\mathrm{mg} / \mathrm{dL}$.

Food was withdrawn in the night before experiments ( 12 hours before). Glycaemia was measured as described above immediately before and at 30 and $120 \mathrm{~min}$ after glucose $(1 \mathrm{~g} / \mathrm{kg}$ in saline solution, i.p.) administration. The glycemic response during GTT was evaluated by the area under the curve (AUC) and incremental area under the curve (IAUC) method. AUC and IAUC results were expressed in $\min . \mathrm{mg} / \mathrm{dL}$. 


\section{Tissue preparation}

At the end of the six weeks of treatment, 48 hours after the last session to avoid its acute effects, animals were euthanized by guillotine for rodents. Metabolic tissues were collected and weighted (grams): liver, gastrocnemius and soleus muscle, pancreas and epididymal white adipose tissue (EWAT). We choose gastrocnemius and soleus muscle due to the different metabolism; gastrocnemius mainly composed by fast twitch fiber and glycolytic, and soleus a predominantly slow twitch, oxidative-fiber-type muscle (PETRY et al., 2019). The EWAT, as a visceral depot, presents a higher metabolic rate and is closely associated with insulin resistance and cardiometabolic risks (OIKONOMOU; ANTONIADES, 2018; COSTA BEBER et al., 2020). Mainly the EWAT redox status can provide important information about the systemic redox profile and glucose intolerance (COSTA BEBER et al., 2020).

Tissues were frozen by liquid nitrogen and maintained at $-20^{\circ} \mathrm{C}$ until the biochemical analysis. Then, still frozen tissues were homogenized in potassium phosphate buffer ( $\mathrm{KPi}, \mathrm{pH} 7.4)$, containing proteases inhibitor PMSF (Phenyl Methyl Sulfonyl Fluoride, Sigma $^{\circledR}$ P7626, FW $=174.19 \mathrm{~g} / \mathrm{mol} ; 1.74 \mathrm{mg} / \mathrm{mL}$ $=100 \mathrm{mM}$ ) to oxidative stress parameters. Gastrocnemius muscle was also homogenized in sodium dodecyl sulfate (SDS, $0.1 \%(\mathrm{w} / \mathrm{v}))$ buffer to determine HSP70 expression by Western blotting. We used buffer in a proportion of $9 \mathrm{~mL} / \mathrm{g}$ of tissue, except for adipose tissue, that we used $5 \mathrm{~mL} / \mathrm{g}$. Blotting and oxidative stress preparations were further centrifuged into Centribio centrifuge for 10 minutes at $4000 \mathrm{rpm}$. The supernatants were collected.

\section{Evaluation of Oxidative Stress}

\section{Determination of Lipid Peroxidation}

The lipid peroxidation was analyzed using the thiobarbituric acid reactive substances method (TBARS) (BUEGE; AUST, 1978). Homogenates were precipitated with $10 \%$ trichloroacetic acid (TCA) in the proportion of 3:1 (540 $\mu \mathrm{L}$ TCA and $180 \mu \mathrm{L}$ homogenate) centrifuged and incubated with thiobarbituric acid (TBA) in the proportion of 1:1 (300 $\mu \mathrm{L}$ TBA and 300 $\mu \mathrm{L}$ supernatant) for 15 minutes at $100^{\circ} \mathrm{C}$. After, the absorbance was measured in a spectrophotometer at $535 \mathrm{~nm}$. The malondialdehyde (MDA) standard was prepared from 1.1.3.3-Tetramethoxypropane (points from $0.0005-0.016 \mathrm{mg} / \mathrm{mL}$ ). Results were expressed in $\mathrm{mmol} \mathrm{MDA} / \mathrm{mL}$, normalized for by protein concentration, measured by the Bradford method, at $595 \mathrm{~nm}$, using albumin curve as standard (BRADFORD, 1976). Further, they were normalized by the control and represented as Arbitrary Units.

\section{Determination of superoxide dismutase (SOD) and catalase (CAT) activity}

The total SOD activity was performed by inhibition of the auto-oxidation of pyrogallol (Marklund e Marklund, 1974). Briefly, in a cuvette, $970 \mu \mathrm{L}$ of 50 mM Tris/ 1mM EDTA buffer (pH 8.2), $4 \mu \mathrm{L}$ of CAT (CAT; $30 \mu \mathrm{M}), 10 \mu \mathrm{L}$ of homogenate were added, the equipment was cleared and $16 \mu \mathrm{L}$ of pyrogallol $(24 \mathrm{mM}$ in $\mathrm{HCl} 10 \mathrm{mM}$ ) were added. The SOD activity was determined at $36^{\circ} \mathrm{C}$ in a spectrophotometer $(420 \mathrm{~nm})$, every 20 seconds, during 120 seconds. The results were expressed in USOD/mg prot.

The CAT activity was performed by the decomposition of hydrogen peroxide (Aebi, 1984). In a quartz cuvette, $955 \mu \mathrm{L}$ of phosphate buffer $(50 \mathrm{mM}, \mathrm{pH}$ 7.4) and $10 \mu \mathrm{L}$ of homogenate were added, the equipment was cleared and $35 \mu \mathrm{L}$ of hydrogen peroxide $(0.01 \mathrm{M})$ were mixed. The CAT activity was determined at $36^{\circ} \mathrm{C}$ in a spectrophotometer ( $240 \mathrm{~nm})$, every 15 seconds, during 120 seconds. The results were expressed in $\mathrm{pmol} / \mathrm{mg}$ prot.

SOD and CAT activities were normalized by protein concentration. Further, they were normalized by the control and represented as Arbitrary Units.

\section{HSP70 muscle expression (iHSP70)}

The iHSP70 expression was evaluated in gastrocnemius tissue by western blotting analyses. Equivalent amounts of protein from each sample ( 40 $\mu \mathrm{g}$ ) were prepared in sample buffer [Tris $50 \mathrm{mM}$, SDS $10 \%$, glycerol $10 \%$, 2-mercaptoethanol $10 \%$ and $2 \mathrm{mg} /$ $\mathrm{ml}$ bromphenol blue]. The samples were boiled for 10 min and electrophoresed in a $10 \%$ polyacrylamide gel ( $5 \mathrm{~h}$ in $15 \mathrm{~mA} / \mathrm{gel}$ ). After, the proteins were transferred to a nitrocellulose membrane (GE HealthCare) by electrotransfer ( $1 \mathrm{~h}$ in $100 \mathrm{~V}$ ) and subsequently, transferred bands were visualized with $0.3 \%(w / v)$ Red Ponceau S (Sigma-Aldrich).

Membranes were washed with washing buffer [TEN-Tween 20 solution $(0.1 \% \mathrm{w} / \mathrm{v})$ : TEN is $50 \mathrm{mM}$ Tris, $5 \mathrm{mM}$ EDTA, $150 \mathrm{mM} \mathrm{NaCl}, \mathrm{pH}$ 7.4]; and then blocked in $5 \%(\mathrm{w} / \mathrm{v})$ nonfat dry milk in washing buffer. Membranes were incubated for 12 hours with monoclonal anti-HSP70 antibody (Sigma-Aldrich H5147, 1:1000). After three consecutive washings with washing buffer, peroxidase-labeled rabbit anti-mouse IgG (Sigma-Aldrich A9044, Lot \# 018M4899V, 1:15000) 
was utilized as secondary antibody. Membrane were incubated for one hour, and after this, were washed tree times on washing buffer. As a gel loading control, we used Coomassie Blue $(0.1 \%$ Coomassie blue, $40 \%$ methanol, $10 \%$ acetic acid) to detect the $43 \mathrm{kDa} \beta$-actin region. Blot visualization was performed using ECL-Prime Western Blotting Reagent (GE Healthcare ${ }^{\circledR}$ ). Quantification of bands was performed using Image ${ }^{\circledR}$ software. The data were presented in arbitrary units of iHSP70, relative do control.

\section{Statistical analyses}

First, we verified the Gaussian distribution of the data, by performing the D'Agoustino-Pearson and Shapiro-Wilk normality tests. Further, assuming the normality, we used two-way ANOVA followed by Tukey to test the effect of time and of the interventions on body weight and GTT. Area under the curve (AUC) and incremental area under the curve (IAUC) were calculated to GTT curve. One-way Anova, followed by Tukey for comparison between groups. We also performed
Pearson's correlation between some variables. All data were expressed in mean \pm SD. We considered a significance level of $95 \%$ and a P 0.05 .

\section{RESULTS}

L-glutamine does not affect the moderate training-induced reduction of adiposity and enhances the gastrocnemius mass in trained animals

Six weeks of moderate aerobic training did not affect the weight during the experiment $(P=0.248)$ (Figure $2 A$ ), except in the $6^{\text {th }}$ week, when the Ex presented lower body weight than Cont and Glut groups $\left(P=0.001, F_{3,22}=7.143\right)$ (Figure 2B). Neither moderate training nor the L-glutamine changed the weight gain during the experiment $\left(P=0.215, F_{3,24}=1.601\right)$ (Figure S1A), Lee Index in the $3^{\text {rd }}\left(P=0.689, F_{3,26}=0,493\right)$ (Figure S1B), and $6^{\text {th }}$ weeks $\left(P=0.718, F_{3,24}=0.451\right.$ ) (Figure S1C).

Ex and Ex+Glut presented lower EWAT mass compared to Cont group, while Glut presented higher adiposity than Cont group $\left(P=0.0003, F_{3,22}=9.518\right)$

Figure 2 - Effect of association of L-glutamine supplementation in animals submitted to moderate aerobic training on body weight, adiposity and gastrocnemius mass

B
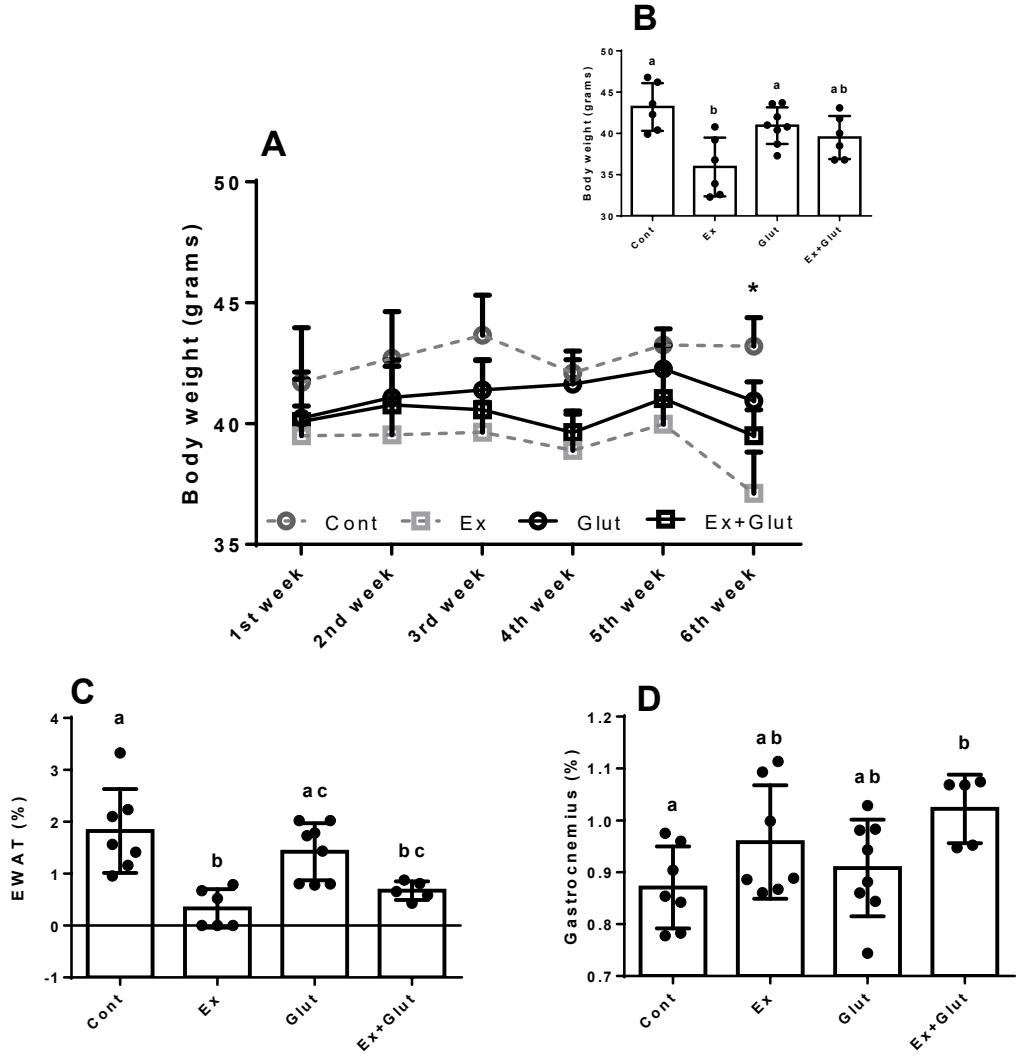

A) Body weight during the 12 weeks. Two-way ANOVA with repeated measures, followed by the Tukey test. Time $P=0.024$, Interventions $P=0.248$, Interaction between factors $P=0.591, *$ Ex vs Cont. B) Final body weight. One-way ANOVA, followed by Tukey test $(P=0.001, F=7.143)$. C) Epididymis white adipose tissue (EWAT). One-way ANOVA, followed by Tukey test $\left(P=0.0003, F_{3,22}=9.518\right)$. D) Gastrocnemius mass. One-way ANOVA, followed by Tukey test $(P=0.045$, $\left.F_{3,23}=3.117\right)$. Data presented as mean \pm SD $(n=6-8 \mathrm{p} /$ group). a-c Means within a row with different superscripts are different at $P$ 0.05. Different letters represent different means while equal letters represent equal means.

Font: The authors. 
Table 1 - Metabolic tissue's weight of animals submitted to moderate aerobic training and L-glutamine supplementation

\begin{tabular}{cccccc}
\hline Tissue mass (\%) & Cont & Ex & Glut & Ex + Glut & P value \\
\hline Soleus muscle & $0.044 \pm 0.006$ & $0.052 \pm 0.010$ & $0.045 \pm 0.004$ & $0.042 \pm 0.004$ & $0.100\left(F_{3,24}=2.326\right)$ \\
Pancreas & $0.521 \pm 0.042$ & $0.565 \pm 0.040$ & $0.555 \pm 0.050$ & $0.555 \pm 0.052$ & $0.379\left(F_{3,23}=1.075\right)$ \\
Liver & $4.118 \pm 0.341$ & $3.960 \pm 0.537$ & $3.825 \pm 0.213$ & $4.020 \pm 0.530$ & $0.591\left(F_{3,24}=0.648\right)$ \\
\hline
\end{tabular}

Data expressed as mean \pm SD. One-way ANOVA, followed by Tukey ( $n=6-8 \mathrm{p} /$ group).

Font: The authors.

Table 2 - Fasting glycaemia of animals submitted to animals submitted to moderate aerobic training and L-glutamine supplementation

\begin{tabular}{cccccc}
\hline Glycaemia & Cont & Ex & Glut & Ex + Glut & P value \\
\hline Baseline & $135.00 \pm 17.76$ & $121.70 \pm 12.68$ & $115.10 \pm 47.38$ & $114.80 \pm 29.64$ & $0.590\left(F_{3,24}=0.650\right)$ \\
$3^{\text {rd }}$ week & $117.30 \pm 28.92$ & $96.71 \pm 27.22$ & $124.40 \pm 28.79$ & $110.30 \pm 40.70$ & $0.393\left(F_{3,24}=1.040\right)$ \\
$6^{\text {th }}$ week & $123.00 \pm 21.27$ & $111.40 \pm 27.46$ & $114.10 \pm 14.75$ & $108.50 \pm 23.67$ & $0.655\left(F_{3,24}=0.545\right)$ \\
\hline
\end{tabular}

Data expressed as mean \pm SD. One-way ANOVA, followed by Tukey ( $n=5-6 \mathrm{p} /$ group).

Font: The authors.

(Figure 2C). Ex+Glut presented a slight higher gastrocnemius mass than Cont group $\left(P=0.045, F_{3,23}=3.117\right)$ (Figure 2D). Therefore, the moderate aerobic training reduces the adiposity independent of supplementation; however, L-glutamine helps in maintaining the lean mass, which explains the lack of effect in the total body weight. Neither the moderate training nor the L-glutamine supplementation affected the mass of the other metabolic tissues, such as soleus muscle, pancreas and liver (Table 1). The biometrical effects were independent of changes in the food $\left(P=0.744, F_{3,44}=\right.$ 0.413) (Figure S1D) and water intake $\left(P=0.3614, F_{3,43}\right.$ = 1.095) (Figure S1E).

Both moderate aerobic training and L-glutamine supplementation enhances the glucose tolerance

Neither moderate training nor the L-glutamine supplementation changed the fasting glycaemia during the experiment (Table 2). However, to verify if the L-glutamine could improve the glucose tolerance in trained animals, we performed GTT at the $3^{\text {rd }}$ and $6^{\text {th }}$ weeks of experiment. At the $3^{\text {rd }}$ week, the GTT was not affected by the interventions $\left(P=0.199, F_{3,24}=1.674\right)$ (Figure 3A), neither was the GTT-AUC $\left(P=0.100, F_{3,24}\right.$ $=2.321$ ) (Figure S2A). However, Ex+Glut presented a lower IAUC than Ex and Glut groups $\left(P=0.006, F_{3,22}=\right.$ 5.290) (Figure 3B). At the $6^{\text {th }}$ week, the GTT was also not affected by the interventions $\left(P=0.205, F_{3,24}=\right.$ 1.643) (Figure 2D), neither the GTT-AUC ( $P=0.168, F_{3}$,
${ }_{24}=1.833$ ) (Figure S2B). However, the IAUC was lower in all groups compared to Cont group $\left(P=0.005, F_{3}\right.$, ${ }_{21}=5.534$ ) (Figure 3D). Taking together, these results shows that the association between L-glutamine supplementation and moderate aerobic exercise improves the glucose tolerance, without affecting the glucose overload-induced glycemic peak. Besides, the association anticipates the IAUC improvement compared to the effects each intervention isolated.

L-glutamine supplementation induces the antioxidant defense in metabolic tissues of animals submitted to moderate aerobic training

Ex+Glut group presented higher lipoperoxidation in the gastrocnemius muscle than Cont and Ex groups $\left(P=0.022, F_{3,23}=3.854\right)$ (Figure $4 A$ ). The association of L-glutamine supplementation and moderate aerobic training slightly increased the SOD activity in Ex+Glut animals compared to Cont $(P=0.044$, $F_{3,24}=3.125$ ) (Figure 4B). L-glutamine also increased the CAT activity in Ex+Glut compared to Ex group ( $P$ $=0.027, F_{3,22}=3.678$ ) (Figure $4 C$ ). Neither moderate aerobic training nor the L-glutamine supplementation affected the lipoperoxidation in the pancreas tissue ( $P$ $=0.062, F_{3,22}=2.826$ ) (Figure 4D). L-glutamine supplementation also increased the SOD activity in trained animals, as verified by the higher SOD activity presented by the Ex+Glut compared to Ex group $(P=0.031$, $F_{3,21}=3.581$ ) (Figure 4E). L-glutamine, moderate ae- 
Figure 3 - Effect of association of L-glutamine supplementation in animals submitted to moderate aerobic training in the GTT response and AUC
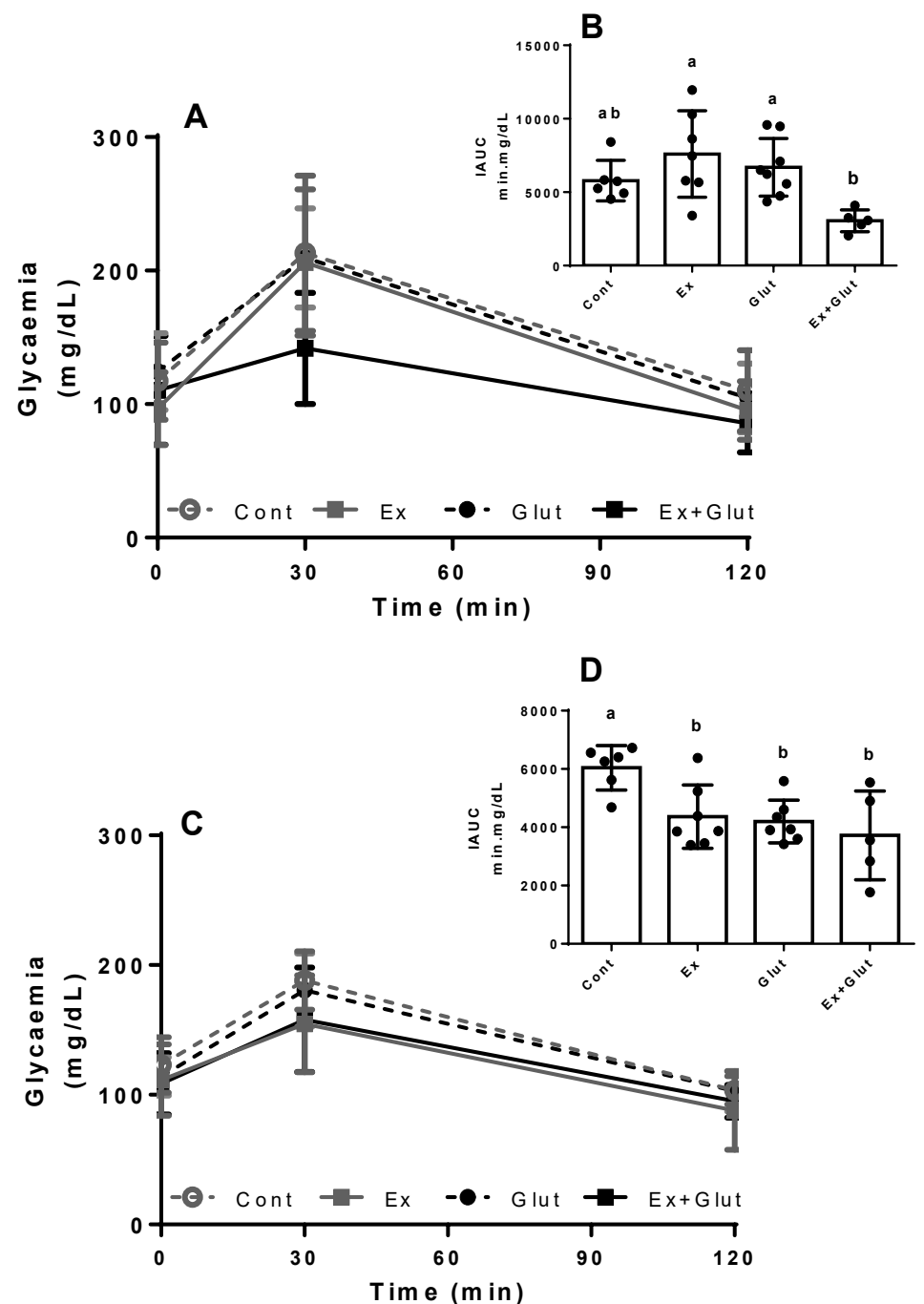

A) GTT response at $3^{\text {rd }}$ week, Two-way ANOVA, followed by Tukey $\left(P=0.199, F_{3,24}=1.674\right)$. B) IAUC at $3^{\text {rd }}$ week, One-way ANOVA, followed by Tukey $(P=0.006$, $\left.F_{32}=5.290\right)$. C) GTT response at $6^{\text {th }}$ week, Two-way ANOVA, followed by Tukey $\left(P=0.205, F_{3}=1.643\right)$ D) IAUC at $6^{\text {th }}$ week, One-way ANOVA, followed by Túkey $\left(P=0.005, F_{3,21}=5.534\right)$. Data expressed in mean $\pm S D(n=6-8$ p/group). a-c Means within a row with different superscripts are different at $P 0.05$. Different letters represent different means while equal letters represent equal means.

Font: The authors.

robic training and both associated increased the CAT activity compared to Cont group $\left(\mathrm{P}=0.0007, \mathrm{~F}_{3,21}=\right.$ 8.514) (Figure 4F).

Neither the lipoperoxidation $\left(P=0.697, F_{3,24}=\right.$ 0.483 ) (Figure $4 G)$ and SOD activity $\left(P=0.086, F_{3,20}=\right.$ 2.526) (Figure $4 \mathrm{H}$ ) were affected by the interventions in the liver tissue. However, Ex group presented lower hepatic CAT activity than Cont, while Glut group presented higher CAT activity than Ex group $\left(P=0.016, F_{3}\right.$, ${ }_{22}=4.266$ ) (Figure 4I). Together, these results suggest that the moderate aerobic training reduced the CAT activity in the liver, while the L-glutamine supplementation attenuated this decrease in the Ex+Glut group. In the epididymis white adipose tissue (EWAT), nei- ther the lipoperoxidation $\left(P=0.106, F_{3,17}=2.376\right)(\mathrm{Fi}-$ gure $4 \mathrm{~L})$, nor the SOD activity $\left(P=0.622, F_{3,20}=0.600\right)$ (Figure 4K) were affected by the interventions. However, the association of L-glutamine supplementation and moderate aerobic training had a slight significant effect in reducing the CAT activity in this tissue compared to Cont group $\left(P=0.049, F_{3,20}=3.101\right.$ ) (Figure $4 \mathrm{~L})$. Therefore, these results suggest that L-glutamine supplementation enhances the antioxidant defense in metabolic tissues, except the adipose tissue.

Furthermore, we also found interesting correlations between some variables. Adiposity was weakly and positively associated with the GTT-AUC at the $6^{\text {th }}$ week ( $r=0.433, P=0.021$ ) (Figure $5 A$ ). Ex+Glut group 
Figure 4 - Effect of association of L-glutamine supplementation in animals submitted to moderate aerobic training on the oxidative parameters in metabolic tissues, gastrocnemius (A-C), pancreas (D-F), liver (G-I) and EWAT (J-L)

\section{Gastrocnemius}

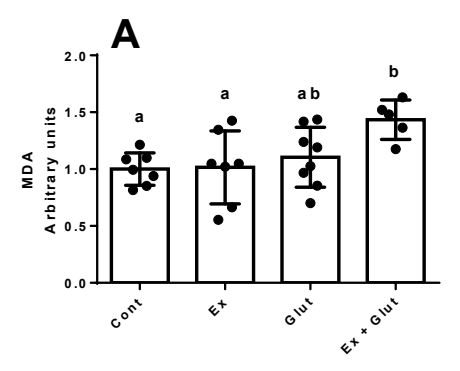

B

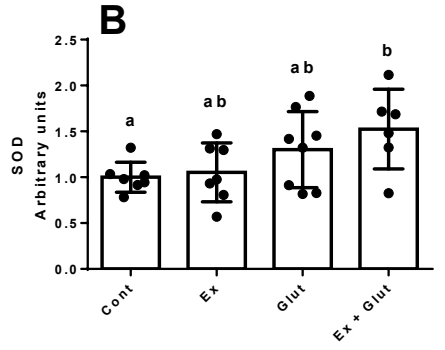

Pancreas
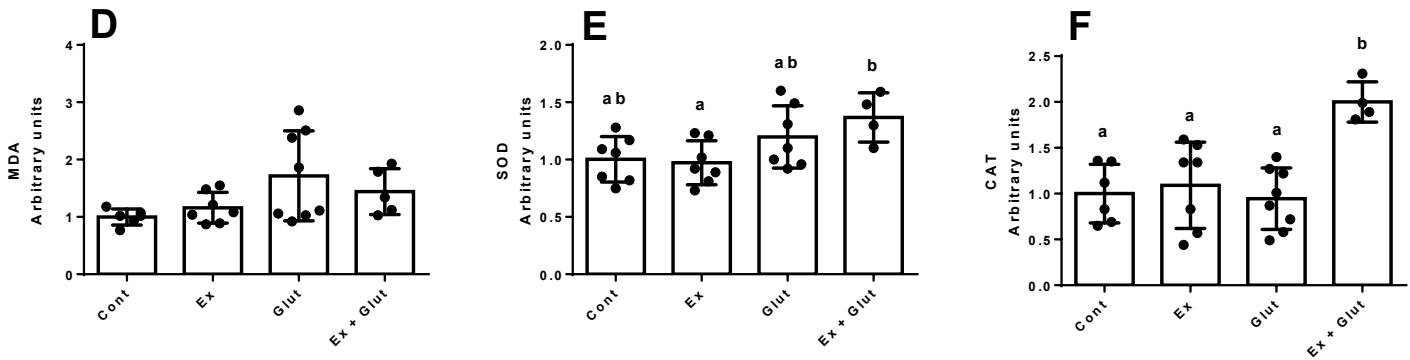

Liver
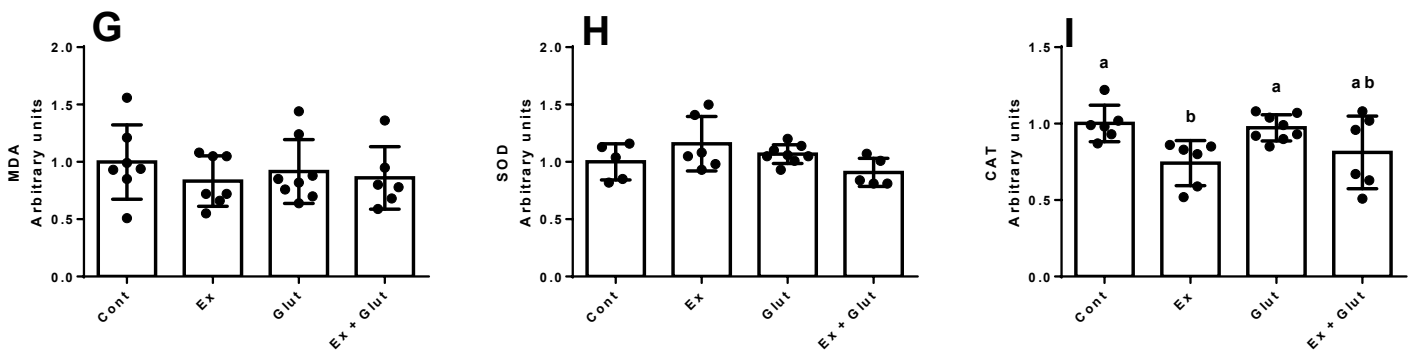

E W A T

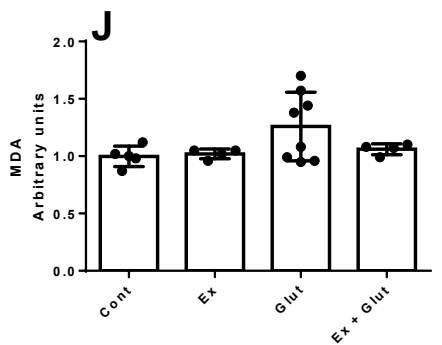

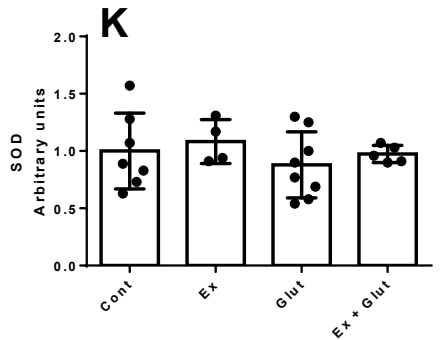

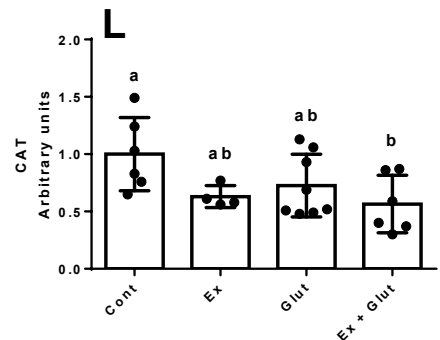

A) Lipoperoxidation $\left(P=0.022, F_{3,23}=3.854\right)$. B) SOD activity $\left(P=0.044, F_{3,2}=3.125\right)$. C $)$ CAT activity $\left(P=0.027, F_{322}=3.678\right)$. $\left.D\right)$ Lipoperoxidation $(P=0.062$, $\left.F_{3,22}=2.826\right)$. E) SOD activity $\left(P=0.031, F_{3,21}=3.581\right)$. $\left.F\right)$ CAT activity $\left(P=0.0007, F_{3,21}=8.514\right)$. $\left.G\right)$ Lipoperoxidation $\left.\left(P=0.697, F_{3,24}=0.483\right) . H\right)$ SOD activity $\left.\left(P=0.086, F_{3,20}=2.526\right) . \mathrm{I}\right)$ CAT activity $\left(P=0.016, F_{3,22}=4.266\right)$. J) Lipoperoxidation $\left.\left(P=0.106, F_{3,17}=2.376\right) . K\right) S O D$ activity $\left.\left(P=0.622, F_{3,20}=0.600\right) . L\right) C A T$ activity $\left(P=0.049, F_{3,20}=3.101\right)$. Data expressed in mean $\pm S D$, relative to Cont group. One-way ANOVA, followed by Tukey ( $\left.n=5-8 p / g r o u p\right)$. $a-c$ Means within a row with different superscripts are different at $P$ 0.05. Different letters represent different means while equal letters represent equal means.

Font: The authors. 


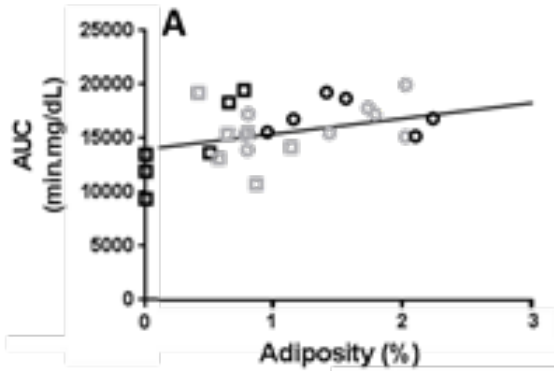

- Cort

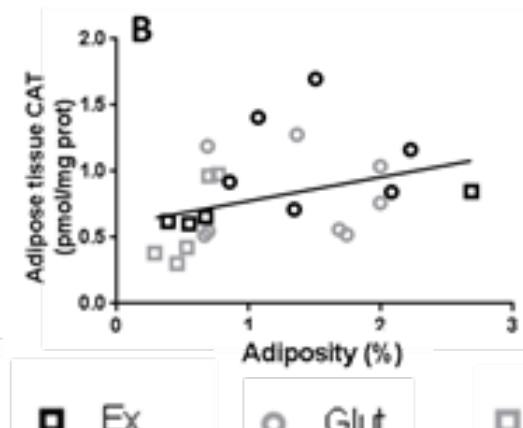

- Ex

○ Glut

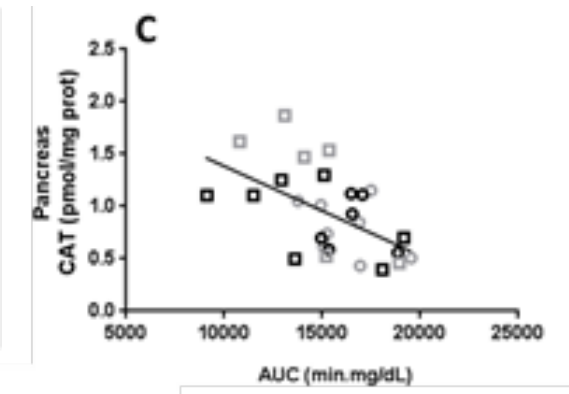

Ex+Glut

A) Adiposity and GTT-AUC at the $6^{\text {th }}$ week $(r=0.433, P=0.021$, all animals together). B) Adiposity and adipose tissue's CAT activity ( $r=0.350$, $P=0.092$, all animals together; $r=0.881, P=0.048$ for Ex+Glut). C) GTT-AUC at the $6^{\text {th }}$ week and pancreas' CAT activity $(r=-0.544, P=0.003)$. Pearson's correlation.

Font: The authors.

also presented a positive association between adiposity and adipose tissue CAT activity $(r=0.881, P=0.048)$ (Figure 5B). Besides, pancreas antioxidant status (CAT activity) was inversely related with the GTT-AUC at the $6^{\text {th }}$ week $(r=-0.544, P=0.003)$ (Figure $5 C$ ).

Neither the physical moderate training nor the L-glutamine supplementation affected the HSP70 expression in the gastrocnemius muscle $\left(P\right.$ 0.999, $F_{3,16}=$ 5,278e-013) (Figure 6).

Figure 6 - Effect of association of L-glutamine supplementation in animals submitted to moderate aerobic training on gastrocnemius HSP70 expression
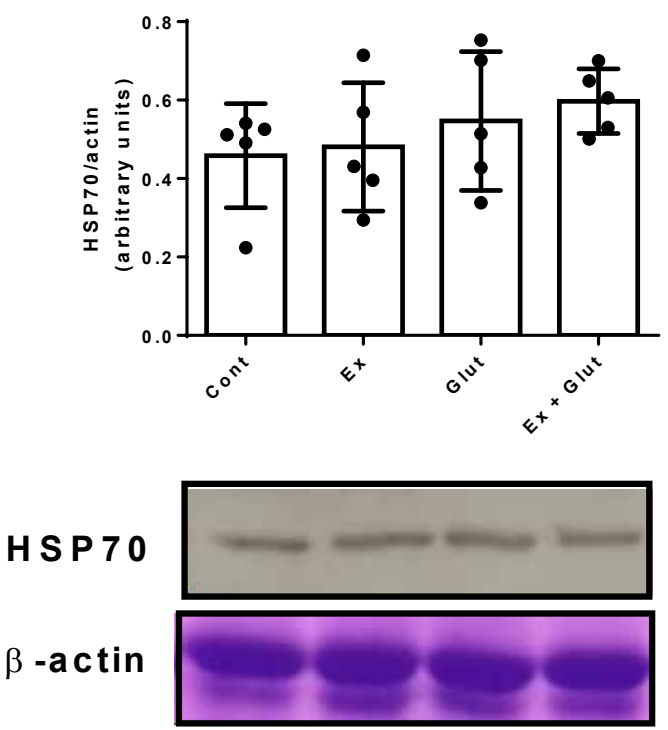

Data expressed in mean $\pm \mathrm{SD}$, relative to Cont group. One-way ANOVA, followed by Tukey (P 0.999, $\left.F_{3,16}=5.278 \mathrm{e}-013\right)(n=5-8 \mathrm{p} /$ group).

Font: The authors.

\section{DISCUSSION}

In our study, the L-glutamine supplementation helped in maintaining the gastrocnemius mass, and improved the glucose tolerance of animals submitted to moderate aerobic training. These effects might be due to the indirect effect of L-glutamine supplementation in the enhancement of the antioxidant activity in metabolic tissues, in a HSP70-independent way.

L-glutamine is one of the most abundant amino acids in the circulation, with a fundamental role in the amino acids and glycemic metabolism. Therefore, the exogenous source of L-glutamine by oral supplementation associated with L-alanine in its free forms, or in alanyl-glutamine dipeptide form can help in the muscle upkeep during catabolic conditions (PETRY et al., 2014, 2019). In our study, we showed that the L-glutamine (without additional alanine) supplementation combined to moderate aerobic training increased the gastrocnemius mass, which explains why this experimental group did not present a decrease in the body weight, induced by the exercise in non-supplemented animals. These biometric effects were independent of food and water intake. Besides, this training protocol reduced the adiposity, independent on L-glutamine supplementation, which contradicts the recent reported possibility of glutamine being lipogenic (COQUEIRO et al. et al., 2019).

Independent of body mass index, low-fitness is associated with central obesity, low-grade inflammation, metabolic diseases and cardiovascular outcomes (WEDELL-NEERGAARD et al., 2018a). Therefore, moderate training can act as a non-pharmacological strategy to prevent and treat metabolic conditions in physically inactive subjects (PEDERSEN, 2017). L-glutamine is a non-essential amino acid, which helps in stimulating insulin secretion and glucose uptake (MEDRAS et al., 2018). Therefore, by helping in glucose uptake and muscle performance (COQUEIRO; ROGERO; TIRAPEGUI, 2019), by reducing about $25 \%$ of the ammonium content (PETRY et al., 2015), we investigated whether the L-glutamine supplementation could also 
exert a synergistic effect in the exercise-induced glucose sensibility. We found that three- and six- weeks of L-glutamine supplementation associated with the moderate aerobic training helped in improve the glucose intolerance, which was related with the decrease of adiposity. This effected preceded the effect of the interventions isolated, which was only perceptible after the 6-weeks following. The protective effect of L-glutamine in the glucose tolerance may be due to the enhancement of the insulin production and secretion (MEDRAS et al., 2018), which helps in augmenting the glucose uptake (CARLESSI et al., 2019). Therefore, these positive effects of L-glutamine may be considered with caution before extrapolating it for obese subjects, since it could be related with a hyperinsulinemia (MEDRAS et al., 2018). Since metabolic disorders or its improvement generally follow oxidative and inflammatory signaling, with HSP70 playing a fundamental role, we investigated whether the L-glutamine could prevent oxidative damage.

In our study, L-glutamine associated to moderate aerobic training increased the lipoperoxidation in the gastrocnemius muscle tissue compared to that observed in the non-supplemented trained animals. Nevertheless, it also increased the muscle SOD and CAT antioxidant activities, the last one compared to non-supplemented trained animals. CAT acts on the SOD-generated $\mathrm{H}_{2} \mathrm{O}_{2}$, while HSP70 inhibits one of the $\mathrm{O}_{2}^{-}$and $\mathrm{H}_{2} \mathrm{O}_{2}$ producers, the NADPH oxidase (NOX) (CHEN et al., 2012). Therefore, the increase of SOD and CAT activity may provide enough antioxidant defense to upkeep its mass during moderate training, explaining why the HSP70 remained unchanged. Moreover, L-glutamine upregulated the SOD and CAT antioxidant activities in pancreas tissue of animals undergoing physical training, which is in agreement with its protective role in diabetic rats' pancreatic islets (MEDRAS et al., 2018; CARLESSI et al., 2019). An increased antioxidant activity in the pancreas may neutralize the ROS production, and suppress the ROS-derived neutralization of insulin (MUNHOZ et al., 2016). Thus, the increased pancreas antioxidant activity may explain the L-glutamine-related enhancement in the glucose tolerance, and this is also supported by the inverse correlation between pancreas CAT activity and the GTT-AUC at the final week.

We also found that, in the adipose tissue (EWAT), the association of L-glutamine and moderate aerobic training reduced the CAT activity. Adipose tissue's antioxidant defense is indirectly related to systemic antioxidant status, marks a metabolic impairment (NEWSHOLME; DE BITTENCOURT, 2014; COSTA
BEBER et al., 2020) and is positively related with the adiposity. Thus, the reduction of its antioxidant defense, together with a reduction of central obesity triggered by the association of exercise and glutamine may represent a better prognostic. The reduced antioxidant defense present by the adipose tissue, contrarily to the increased defense presented by the other metabolic tissues may be associated with the adipose insulin resistance triggered by L-glutamine supplementation, while muscle and liver present an L-glutamine-induced amelioration in these aspects (ABBOUD et al., 2019). In this sense, L-glutamine could contribute to reducing the adiposity, by injuring the adipocytes, through insulin resistance and oxidative stress.

As the central metabolic tissue, liver exerts an essential role supporting glycemic, lipid and protein metabolism, especially under intense exercise. However, if the effects of the L-glutamine supplementation are similar in liver and muscle remained unclear until this moment. A previous study showed that L-glutamine associated to L-alanine in its free form or in the dipeptide form could enhance liver glutamine and GSH content, without affecting the HSP70 expression (PETRY et al., 2015). In our study, we tested if the L-glutamine in its free form could improve the hepatic oxidative status in trained animals. We found that moderate training reduced the CAT activity, while L-glutamine supplementation increased it. Thus, this result show an important target of investigation concerning to the hepatic effects of moderate exercise. Nevertheless, this effect was neutralized when the L-glutamine was combined to training.

L-glutamine has an essential role in maintaining the antioxidant system. However, high-duration or intense exercises deplete the L-glutamine pools and lead to an oxidative condition, here perceptible in the CAT down regulation in the hepatic tissue. Thus, the supplementation could provide an exogenous source of L-glutamine. L-glutamine $(1 \mathrm{~g} / \mathrm{kg})$ combined to L-alanine supplementation increased plasma L-glutamine by approximately 60\% (PETRY et al., 2014, 2015), muscle GSH content by 100\% (PETRY et al., 2014), and liver GSH content by $90 \%$ compared to non-supplemented trained animals (PETRY et al., 2015). However, the oral administration of L-glutamine in its free form has been criticized concerning to its efficacy (CRUZAT et al., 2018), since only half of L-glutamine load supplied by the gastrointestinal route escapes the splanchnic bed (MATTHEWS, 1990; DECHELOTTE et al., 1991). Despites the loss of L-glutamine to en- 
terocytes provision, our results shows that the oral administration is still an efficient way when combined to physical training.

Here, we used a six-weeks moderate aerobic training protocol, which was already validated in previous studies (HECK et al., 2017; MAl et al., 2017; KOSTRYCKI et al., 2019). Since rodents feed with standard diets and remained sedentary tends to develop weight gain and obesity because of the free access to food (MARTIN et al., 2010; SEO et al., 2014), and present an innate swimming ability, the swimming represents a replicable protocol, very similar to the human condition. Besides, eight-weeks training leads to physiological adaptations, such as an improved physical performance, reduction of adiposity and cardiac hypertrophy, whilst enhances the skeletal muscle mass (ARAUJO et al., 2015). In addition, it also improves glycemic and lipid parameters in high fat diet-fed animals (JANG et al., 2014; ARAUJO et al., 2015). Some of these effects are also evident in standard diet-fed animals, following a twelve-weeks swimming protocol (MAl et al., 2017). Taking together, these data enhances the replicability of swimming protocol and highlights the possibility of extending it for longer periods, with a guarantee of physical adaptation.

However, our study has some limitations. Swimming requires a high tissue demand and response, which can be different between animals and humans, because of the size and movement patterns (SEO et al., 2014). Besides, in this study, we only used male mice, and female could respond differently to the training protocol and L-glutamine supplementation, since estrogen per se has a powerful antioxidant activity. Finally, our data concerning to glucose tolerance may be carefully considered before extrapolating these results to an insulin resistant model, since we used standard diet-fed animals.

Taking together, our results show that L-glutamine oral supplementation, even when not associated with L-alanine, improves the biometrical, glycemic and antioxidant status in male mice undergoing moderate aerobic training. These findings are in agreement with a recent report of the benefits of combined exercise training and L-glutamine supplementation in oral redox and inflammatory parameters (ALMEIDA et al., 2020). It is known that L-glutamine supplementation can improve the muscle and liver health by enhancing the glutamine-glutathione-HSF1-HSP70 regulation and protection (PETRY et al., 2014, 2015, 2019). Furthermore, our study show that L-glutamine exerted the improvement in biometric and glycemic metabolism in animals undergoing aerobic training, by an indirect antioxidant activity, enhancing muscle, pancreas and liver antioxidant defenses, but not in EWAT, even without changes to the HSP70 content yet.

\section{CONCLUSION}

In conclusion, the L-glutamine supplementation in its free form, helps in increasing the gastrocnemius mass and improving the glucose tolerance in animals submitted to moderate aerobic training. These benefits are related to the improvement of the antioxidant status verified in the metabolic tissues, gastrocnemius muscle, liver and pancreas in animals undergoing moderate aerobic training. Moreover, our study shows that the L-glutamine-related antioxidant effect extrapolates the already known glutamine-glutathione-HSP70 axis, and enhances other antioxidant enzymes, such as SOD and CAT activities.

\section{REFERENCES}

ABBOUD, K. Y. et al. Oral Glutamine Supplementation Reduces Obesity, Pro-Inflammatory Markers, and Improves Insulin Sensitivity in DIO Wistar Rats and Reduces Waist Circumference in Overweight and Obese Humans. Nutrients, v. 11, n. 3, Mar. 10 2019. ISSN 2072-6643 (Electronic) (Linking). Disponivel em: http://www.ncbi.nlm.nih.gov/ pubmed/30832230.

AEBI, H. Catalase in vitro. Methods Enzymol, v. 105, p. 1216, 1984. ISSN 0076-6879 (Print) 0076-6879 (Linking). Disponível em: https://www.ncbi.nlm.nih.gov/pubmed/6727660.

ALMEIDA, E. B. et al. L-Glutamine Supplementation Improves the Benefits of Combined-Exercise Training on Oral Redox Balance and Inflammatory Status in Elderly Individuals. Oxid Med Cell Longev, v. 2020, p. 2.852.181, 2020. ISSN 1942-0994 (Electronic) 1942-0994 (Linking). Disponível em: http://www.ncbi.nlm.nih.gov/pubmed/32411324.

ARAUJO, L. C. et al. Chronic aerobic swimming exercise promotes functional and morphological changes in rat ileum. Biosci Rep, v. 35, n. 5, Sept. 30 2015. ISSN 1573-4935 (Electronic) 0144-8463 (Linking). Disponível em: http://www. ncbi.nlm.nih.gov/pubmed/26424698.

BITTENCOURT, A. et al. Heat shock response to exercise in pancreatic islets of obese mice. Biochimie, v. 168, p. 28-40, Jan. 2020. ISSN 1638-6183 (Electronic) 0300-9084 (Linking). Disponível em: http://www.ncbi.nlm.nih.gov/ pubmed/31678111.

BRADFORD, M. M. A rapid and sensitive method for the quantitation of microgram quantities of protein utilizing the principle of protein-dye binding. Anal Biochem, v. 72, p. 248-54, May. 7 1976. ISSN 0003-2697 (Print) 0003-2697 (Linking). Disponivel em: https://www.ncbi.nlm.nih.gov/ pubmed/942051. 
BUEGE, J. A.; AUST, S. D. Microsomal lipid peroxidation. Methods Enzymol, v. 52, p. 302-310, 1978. ISSN 0076-6879 (Print) 0076-6879 (Linking). Disponível em: https://www. ncbi.nlm.nih.gov/pubmed/672633.

CARLESSI, R. et al. Glutamine deprivation induces metabolic adaptations associated with beta cell dysfunction and exacerbate lipotoxicity. Mol Cell Endocrinol, v. 491, p. 110.433, July 1 2019. ISSN 1872-8057 (Electronic) 03037207 (Linking). Disponível em: http://www.ncbi.nlm.nih. gov/pubmed/31018148.

CASTELL, L. M.; POORTMANS, J. R.; NEWSHOLME, E. A. Does glutamine have a role in reducing infections in athletes? Eur J Appl Physiol Occup Physiol, v. 73, n. 5, p. 488-90, 1996. ISSN 0301-5548 (Print) 0301-5548 (Linking). Disponível em: http://www.ncbi.nlm.nih.gov/pubmed/8803512.

CHEN, F. et al. Opposing actions of heat shock protein 90 and 70 regulate nicotinamide adenine dinucleotide phosphate oxidase stability and reactive oxygen species production. Arterioscler Thromb Vasc Biol, v. 32, n. 12, p. 298999, Dec. 2012. ISSN 1524-4636 (Electronic) 1079-5642 (Linking). Disponível em: http://www.ncbi.nlm.nih.gov/ pubmed/23023377.

COQUEIRO, A. Y. et al. Effects of Glutamine and Alanine Supplementation on Adiposity, Plasma Lipid Profile, and Adipokines of Rats Submitted to Resistance Training. J Diet Suppl, v. 16, n. 6, p. 676-688, 2019. ISSN 1939-022X (Electronic) 1939-0211 (Linking). Disponível em: http://www. ncbi.nlm.nih.gov/pubmed/29985713.

COQUEIRO, A. Y.; ROGERO, M. M.; TIRAPEGUI, J. Glutamine as an Anti-Fatigue Amino Acid in Sports Nutrition. Nutrients, v. 11, n. 4, Apr 17 2019. ISSN 2072-6643 (Electronic) 2072-6643 (Linking). Disponível em: http://www.ncbi.nlm. nih.gov/pubmed/30999561.

COSTA BEBER, L. C. et al. The association of subchronic exposure to low concentration of PM2.5 and high-fat diet potentiates glucose intolerance development, by impairing adipose tissue antioxidant defense and eHSP72 levels. Environ Sci Pollut Res Int, v. 27, n. 25, p. 32.006-32.016, Sept. 2020. ISSN 1614-7499 (Electronic) 0944-1344 (Linking). Disponível em: http://www.ncbi.nlm.nih.gov/pubmed/32506396.

CRUZAT, V. et al. Glutamine: Metabolism and Immune Function, Supplementation and Clinical Translation. Nutrients, v. 10, n. 11, Oct. 23 2018. ISSN 2072-6643 (Electronic) 20726643 (Linking). Disponível em: http://www.ncbi.nlm.nih. gov/pubmed/30360490.

DECHELOTTE, P. et al. Absorption and metabolic effects of enterally administered glutamine in humans. Am J Physiol, v. 260, n. 5 Pt 1, p. G677-82, May. 1991. ISSN 0002-9513 (Print) 0002-9513 (Linking). Disponível em: http://www. ncbi.nlm.nih.gov/pubmed/1903599.

FIUZA-LUCES, C. et al. Exercise is the real polypill. Physiology (Bethesda), v. 28, n. 5, p. 330-58, Sept. 2013. ISSN 1548-9221 (Electronic) 1548-9221 (Linking). Disponível em: http://www.ncbi.nlm.nih.gov/pubmed/23997192.

GOETTEMS-FIORIN, P. B. et al. Fine particulate matter potentiates type 2 diabetes development in high-fat diet-treated mice: stress response and extracellular to intra- cellular HSP70 ratio analysis. J Physiol Biochem, v. 72, n. 4, p. 643-656, Dec. 2016. ISSN 1877-8755 (Electronic) 11387548 (Linking). Disponível em: https://www.ncbi.nlm.nih. gov/pubmed/27356529.

HECK, T. G. et al. Acute exercise boosts cell proliferation and the heat shock response in lymphocytes: correlation with cytokine production and extracellular-to-intracellular HSP70 ratio. Cell Stress Chaperones, v. 22, n. 2, p. 271-291, Mar. 2017. ISSN 1466-1268 (Electronic) 1355-8145 (Linking). Disponível em: https://www.ncbi.nlm.nih.gov/pub$\mathrm{med} / 28251488$.

JANG, A. et al. The effect of dietary alpha-lipoic acid, betaine, I-carnitine, and swimming on the obesity of mice induced by a high-fat diet. Food Funct, v. 5, n. 8, p. 1966-74, Aug. 2014. ISSN 2042-650X (Electronic) 2042-6496 (Linking). Disponível em: http://www.ncbi.nlm.nih.gov/pubmed/24973338.

KOSTRYCKI, I. M. et al. Effects of High-Fat Diet on eHSP72 and Extra-to-Intracellular HSP70 Levels in Mice Submitted to Exercise under Exposure to Fine Particulate Matter. J Diabetes Res, v. 2019, p. 4.858.740, 2019. ISSN 2314-6753 (Electronic). Disponível em: http://www.ncbi.nlm.nih.gov/ pubmed/30723746.

KREGEL, K. C. A. et al. Resource book for the design of animal exercise protocols. American Physiological Society, 2006.

LEE, M. O. Determination of the surface area of the white rat with its application to the expression of metabolic results. American Journal of Physiology, v. 89, p. 24-33, 1929.

MAl, A. S. et al. Exercise Training under Exposure to Low Levels of Fine Particulate Matter: Effects on Heart Oxidative Stress and Extra-to-Intracellular HSP70 Ratio. Oxid Med Cell Longev, v. 2017, p. 9.067.875, 2017. ISSN 1942-0994 (Electronic) 1942-0994 (Linking). Disponível em: http://www. ncbi.nlm.nih.gov/pubmed/29387296.

MARKLUND, S.; MARKLUND, G. Involvement of the superoxide anion radical in the autoxidation of pyrogallol and a convenient assay for superoxide dismutase. Eur J Biochem, v. 47, n. 3, p. 469-74, Sept. 16 1974. ISSN 0014-2956 (Print) 0014-2956 (Linking). Disponível em: https://www.ncbi.nlm. nih.gov/pubmed/4215654.

MARTIN, B. et al. "Control" laboratory rodents are metabolically morbid: why it matters. Proc Natl Acad Sci U S A, v. 107, n. 14, p. 6.127-6.133, Apr. 6 2010. ISSN 1091-6490 (Electronic) 0027-8424 (Linking). Disponível em: http:// www.ncbi.nlm.nih.gov/pubmed/20194732.

MATTHEWS, D. E. Utilisation of enterally delivered glutamine and glutamate: stable isotope tracer study in healthy humans. Clin Nutr, v. 9, n. 1, p. 50-51, Feb. 1990. ISSN 02615614 (Print) 0261-5614 (Linking). Disponível em: http:// www.ncbi.nlm.nih.gov/pubmed/16837330.

MEDRAS, Z. J. H. et al. Glutamine up-regulates pancreatic sodium-dependent neutral aminoacid transporter-2 and mitigates islets apoptosis in diabetic rats. Pharmacol Rep, v. 70, n. 2, p. 233-242, Apr. 2018. ISSN 1734-1140 (Print)

1734-1140 (Linking). Disponível em: http://www.ncbi.nlm. nih.gov/pubmed/29475006. 
MIRAGEM, A. A.; HOMEM DE BITTENCOURT, P. I., JR. Nitric oxide-heat shock protein axis in menopausal hot flushes: neglected metabolic issues of chronic inflammatory diseases associated with deranged heat shock response. Hum Reprod Update, v. 23, n. 5, p. 600-628, Sept. 1 2017. ISSN 1460-2369 (Electronic) 1355-4786 (Linking). Disponível em: http://www.ncbi.nlm.nih.gov/pubmed/28903474.

MUNHOZ, A. C. et al. Control of Insulin Secretion by Production of Reactive Oxygen Species: Study Performed in Pancreatic Islets from Fed and 48-Hour Fasted Wistar Rats. PLoS One, v. 11, n. 6, p. e0158166, 2016. ISSN 1932-6203 (Electronic) 1932-6203 (Linking). Disponível em: http:// www.ncbi.nlm.nih.gov/pubmed/27362938.

NEWSHOLME, P.; DE BITTENCOURT, P. I., JR. The fat cell senescence hypothesis: a mechanism responsible for abrogating the resolution of inflammation in chronic disease. Curr Opin Clin Nutr Metab Care, v. 17, n. 4, p. 295-305, Jul. 2014. ISSN 1473-6519 (Electronic) 1363-1950 (Linking). Disponível em: http://www.ncbi.nlm.nih.gov/pubmed/24878874.

OIKONOMOU, E. K.; ANTONIADES, C. The role of adipose tissue in cardiovascular health and disease. Nat Rev Cardiol, Oct. 4 2018. ISSN 1759-5010 (Electronic) 1759-5002 (Linking). Disponível em: http://www.ncbi.nlm.nih.gov/ pubmed/30287946.

PEDERSEN, B. K. Muscle as a secretory organ. Compr Physiol, v. 3, n. 3, p. 1337-62, Jul. 2013. ISSN 2040-4603 (Electronic) 2040-4603 (Linking). Disponível em: http://www. ncbi.nlm.nih.gov/pubmed/23897689.

PEDERSEN, B. K.Anti-inflammatory effects of exercise: role in diabetes and cardiovascular disease. Eur J Clin Invest, v. 47, n. 8, p. 600-611, Aug. 2017. ISSN 1365-2362 (Electronic) 0014-2972 (Linking). Disponível em: http://www.ncbi.nlm. nih.gov/pubmed/28722106.

PETRY, E. R. et al. L-glutamine supplementations enhance liver glutamine-glutathione axis and heat shock factor-1 expression in endurance-exercise trained rats. Int J Sport Nutr Exerc Metab, v. 25, n. 2, p. 188-97, Apr. 2015. ISSN 1543-2742 (Electronic) 1526-484X (Linking). Disponível em: http://www.ncbi.nlm.nih.gov/pubmed/25202991.

PETRY, E. R. et al. Alanyl-glutamine and glutamine plus alanine supplements improve skeletal redox status in trained rats: involvement of heat shock protein pathways. Life Sci, v. 94, n. 2, p. 130-6, Jan. 17 2014. ISSN 1879-0631 (Electronic) 0024-3205 (Linking). Disponível em: http://www.ncbi.nlm. nih.gov/pubmed/24269578.

PETRY, E. R. et al. Oral glutamine supplementation attenuates inflammation and oxidative stress-mediated skeletal muscle protein content degradation in immobilized rats: Role of $70 \mathrm{kDa}$ heat shock protein. Free Radic Biol Med, v. 145, p. 87-102, Dec. 2019. ISSN 1873-4596 (Electronic) 0891-5849 (Linking). Disponível em: http://www.ncbi.nlm. nih.gov/pubmed/31505269.

SCHOLER, C. M. et al. Modulation of rat monocyte/macrophage innate functions by increasing intensities of swimming exercise is associated with heat shock protein status.
Mol Cell Biochem, v. 421, n. 1-2, p. 111-25, Oct. 2016. ISSN 1573-4919 (Electronic) 0300-8177 (Linking). Disponível em: http://www.ncbi.nlm.nih.gov/pubmed/27522667.

SEO, D. Y. et al. Humanized animal exercise model for clinical implication. Pflugers Arch, v. 466, n. 9, p. 1.6731.687, Sept. 2014. ISSN 1432-2013 (Electronic) 0031-6768 (Linking). Disponível em: http://www.ncbi.nlm.nih.gov/ pubmed/24647666.

SULZBACHER, M. M. S. et al. Efeitos do tratamento com glutamina via enteral em modelo animal de sepse. Revista Saúde (Santa Maria), v. 42, n. 2, p. 1-10, 2018.

WEDELL-NEERGAARD, A. S. et al. Low fitness is associated with abdominal adiposity and low-grade inflammation independent of BMI. PLoS One, v. 13, n. 1, p. e0190645, 2018a. ISSN 1932-6203 (Electronic) 1932-6203 (Linking). Disponível em: http://www.ncbi.nlm.nih.gov/pubmed/29342196.

WEDELL-NEERGAARD, A. S. et al. Cardiorespiratory fitness and the metabolic syndrome: Roles of inflammation and abdominal obesity. PLoS One, v. 13, n. 3, p. e0194991, 2018 b. ISSN 1932-6203 (Electronic) 1932-6203 (Linking). Disponível em: http://www.ncbi.nlm.nih.gov/pubmed/29590212. 


\section{SUPPLEMENTARY MATERIAL}

Table S1 - A detailed description of the standard diet (Nuvilab CR-1, commercially obtained from Nuvital Nutrientes SA)

\begin{tabular}{cc}
\hline Component & Content \\
\hline Crude protein & $220 \mathrm{~g} / \mathrm{kg}$ \\
Ethereal extract & $40 \mathrm{~g} / \mathrm{kg}$ \\
Mineral material & $90 \mathrm{~g} / \mathrm{kg}$ \\
Crude fiber & $70 \mathrm{~g} / \mathrm{kg}$
\end{tabular}

\section{Vitamins}

Vit A

Vit D3

Vit E

Vit K3

Vit B1

Vit B2

Vit B6

Vit B12

Niacin

Calcium pantothenate

Folic acid

Biotin

Choline

Sodium minerals

Manganese

Zinc

Copper

lodine

Selenium

Cobalt

Fluorine

Iron

Lysine

Methionine
$13000 \mathrm{U} / \mathrm{kg}$

$2000 \mathrm{U} / \mathrm{kg}$

$34 \mathrm{U} / \mathrm{kg}$

$3 \mathrm{mg} / \mathrm{kg}$

$5 \mathrm{mg} / \mathrm{kg}$

$6 \mathrm{mg} / \mathrm{kg}$

$7 \mathrm{mg} / \mathrm{kg}$

$22 \mathrm{mcg} / \mathrm{kg}$

$60 \mathrm{mg} / \mathrm{kg}$

$20 \mathrm{mg} / \mathrm{kg}$

$1 \mathrm{mg} / \mathrm{kg}$

$0.05 \mathrm{mg} / \mathrm{kg}$

$1900 \mathrm{mg} / \mathrm{kg}$

$2700 \mathrm{mg} / \mathrm{kg}$

$60 \mathrm{mg} / \mathrm{kg}$

$60 \mathrm{mg} / \mathrm{kg}$

$10 \mathrm{mg} / \mathrm{kg}$

$2 \mathrm{mg} / \mathrm{kg}$

$0.05 \mathrm{mg} / \mathrm{kg}$

$5 \mathrm{mg} / \mathrm{kg}$

$80 \mathrm{mg} / \mathrm{kg}$

$50 \mathrm{mg} / \mathrm{kg}$

Amino acids

$12 \mathrm{~g} / \mathrm{kg}$

$4000 \mathrm{mg} / \mathrm{kg}$

\section{Addictions}

BHT $100 \mathrm{mg} / \mathrm{kg}$

U - International Unit

Font: The authors. 
Figure S1 - Effect of association of L-glutamine supplementation in animals submitted to moderate aerobic training on weight gain, Lee Index, food and water intake
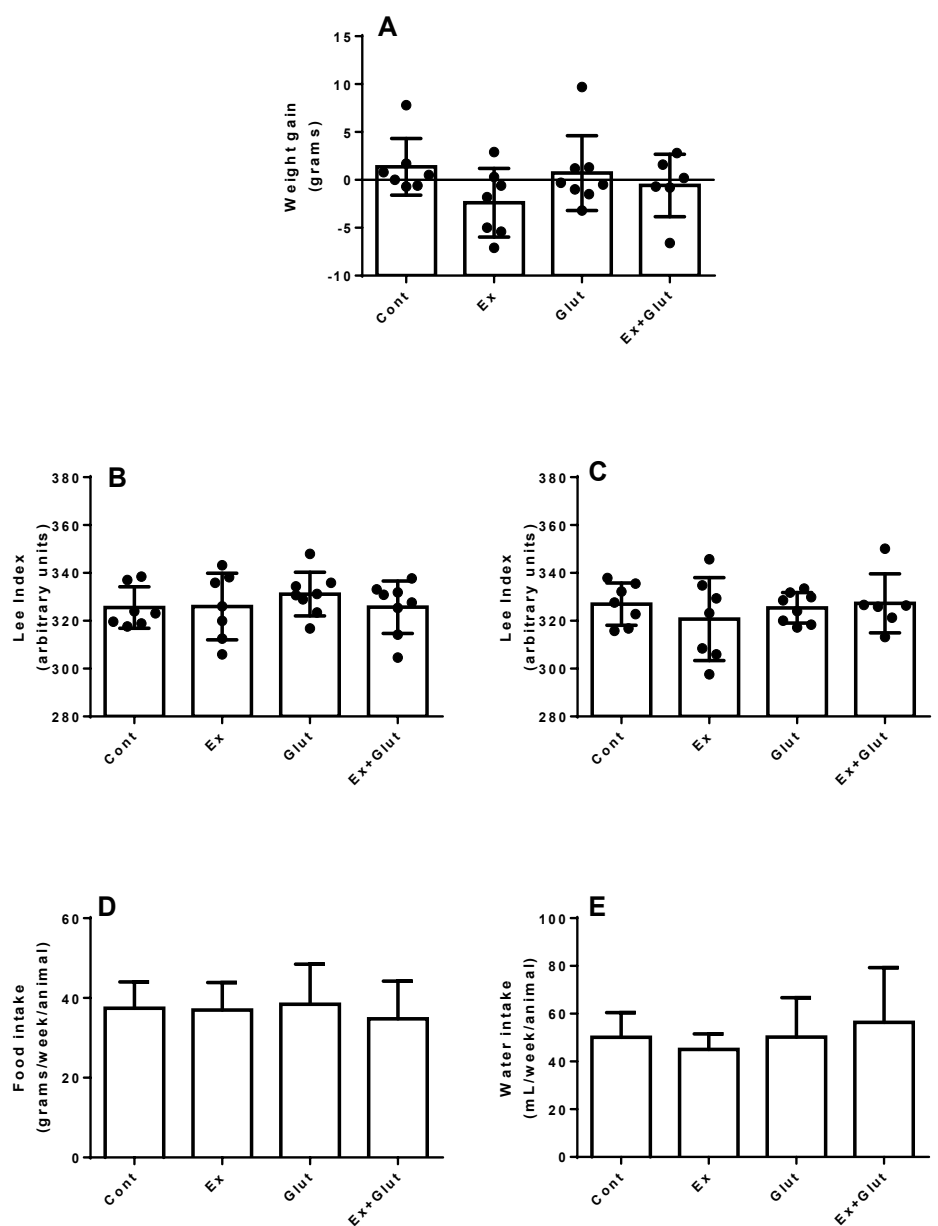

A) Weight gain $\left(P=0.215, F_{3,24}=1.601\right)$. B) Lee Index at the 3rd week $\left(P=0.689, F_{3,26}=0.493\right)$. C) Lee Index at the 6th week $\left(P=0.718, F_{3,24}=0.451\right)$. D) Food intake $\left(P=0.744, F_{3,44}=0.413\right)$. E) Water intake $\left(P=0.3614, F_{3,43}=1.095\right)$. Data presented as mean $\pm S D$. One-way ANOVA, followed by Tukey $(n=6-8 p /$ group). Font: The authors.

Figure S2 - Effect of association of L-glutamine supplementation in animals submitted to moderate aerobic training on GTT-AUC
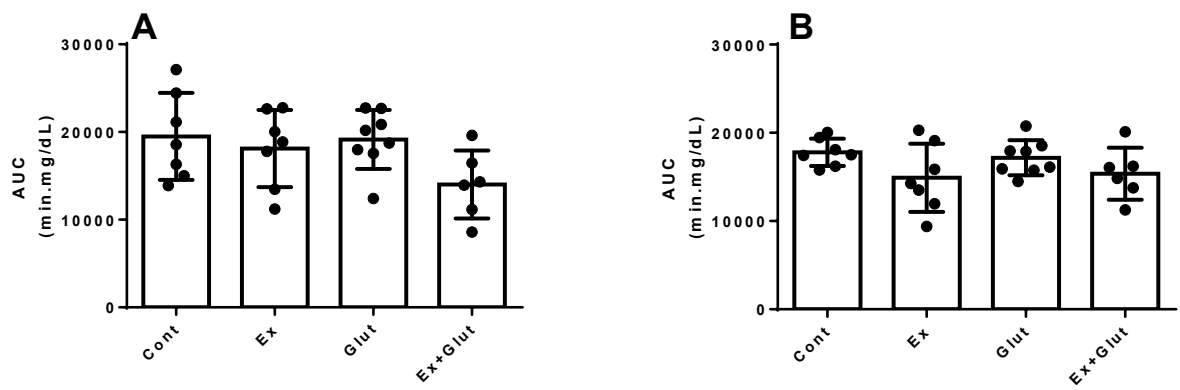

A) AUC-GTT $3^{\text {rd }}$ week $\left(P=0.100, F_{3,24}=2.321\right)$. B) AUC-GTT $6^{\text {th }}$ week $\left(P=0.168, F_{3,24}=1.833\right)$. Data presented as mean \pm SD. One-way ANOVA, followed by Tukey ( $n=6-8 \mathrm{p}$ /group).

Font: The authors. 